\title{
New wine in old bottles: output and productivity trends in Portuguese agriculture, 1850-1950*
}

European Review of Economic History, 2003, vol. 7, no. 1, pp. 43-42.

\author{
Pedro Lains \\ Instituto de Ciências Sociais, \\ Universidade de Lisboa \\ R. Miguel Lupi, 18, r/c, 1200-725 Lisboa, Portugal \\ Pedro.Lains@ics.ul.pt
}

(October 2002)

\begin{abstract}
$\underline{\text { Abstract }}$
Recent studies on European agricultural history have shown that, during the early phases of economic development, agricultural growth can occur in the absence of major institutional changes. This paper extends such a conclusion - of agricultural growth without major institutional change - to the case of Portugal during the period from 1850 to 1950. Based on new indices for agricultural output growth and data on the use of inputs, we show in the paper that Portuguese agriculture was not stagnant in that century and that output and labour productivity expanded rapidly, in particular in the decades from 1870-1900 and 1930-50. We propose an explanation for the positive performance of the agricultural sector which is related to the changing patterns in the use of land and in the product mix, and to the growth of domestic demand for agricultural produce.
\end{abstract}




\section{Introduction}

The slow development of the agricultural sector, in terms of transformations in production and organisation methods, can be a major feature of European economies in the earlier stages of development. Yet the slow pace of institutional change and slow innovation in agriculture is not necessarily associated with the absence of output growth of in the agricultural sector. In fact, it has been shown for France, during the last century of the Ancien Régime (Grantham 1989, Hoffman 1996), and for Italy and Spain, during most of the nineteenth century (O’Brien and Toniolo 1986, Prados 1988, Simpson 1995, Morilla et al. 1999), that there was agricultural growth in the absence of major institutional and organizational changes of the sort that occurred in more advanced economies, namely in Great Britain.

New indices for Portuguese agricultural output growth (Batista et al. 1997, Lains and Sousa 1998) and data on the evolution of the agricultural labour force and the use of land, provide the basis for a revision of the performance of Portugal's agriculture in a comparative framework, during the century of 1850-1950. In fact, the new data show that the sector experienced a relatively rapid growth, in terms of output and factor productivity, in two different instances. The first was during the last three decades of the nineteenth century, when output increased at 1.4 per cent per year; the second instance occurred during the period from about 1930 to 1950, when output expanded at 2.4 per cent per year (both rates in real terms). Moreover, in this later period, agricultural labour productivity increased at 1.5 per cent per year, which compares rather favourably with contemporary trends elsewhere in Europe. It is also important to note that, between 1930 and 1950, Portuguese agricultural output increased 
at a rate similar to that of the industrial sector and slightly above the rate of growth of total GDP (due to slower growth in the services sector), which meant that the share of agriculture in total GDP remained stable between 1930 and 1950.

The absence of major institutional changes does not seem to have hampered the growth of agricultural output and productivity in Portugal. Yet, in a European perspective, the Portuguese agricultural sector remained largely backward in terms of the persistence of the use of traditional methods and traditional crops, and the limited use of animals, modern tools and, later on, machinery. In order to understand the maintenance of such practices, we need to understand the true causes of slow agricultural change, other than the lack of major institutional reforms. In other words, we need to know if the reasons for backwardness in agriculture are primarily located within the sector or outside it (Moore 1945, Ruttan 1978, Prados 1988).

The present paper analyses the determinants of growth of agricultural labour productivity in Portugal in two steps. Firstly, we analyse productivity growth in terms of changes in the ratio of agricultural area per agricultural worker and in terms of changes in the ratio of agricultural output per agricultural area (Hayami and Ruttan 1971, O’Brien and Keyder 1978, Pereira and Estácio 1968). Before 1930, the land-labour ratio increased slightly or remained stable, as changes in the extension of agricultural area were matched by changes in the size of the labour force, and output per hectare increased only slightly. After 1930, the land-labour ratio declined and yet output per hectare increased at an unprecedented pace. In order to understand the causes behind the increase in Portuguese agricultural labour productivity, during this latter period, we have to analyse the reasons behind the increase in output per unit of land. As such, in a second step this paper analyses the increase in output per hectare in terms of changes in yields and product mix. Despite the intensification in the use of chemical fertilizers and the higher growth of the stock of capital, yields did not increase 
significantly after 1930. It will be shown that a large share of the increase in agricultural output is explained by the increase in the sectors with higher levels of land productivity, particularly in the period of rapid growth after 1930.

The fact that changes in the product mix show up as more important in explaining the increase in land productivity leads to the study of demand for agricultural produce. It will be shown here that domestic demand for agricultural produce increased more rapidly, after 1930, which went along with an increase in the pace of industrialisation, and thus the Portuguese agricultural sector faced positive prospects for growth. As a result, the increasing pressure of a growing agricultural labour force on a fixed amount of land was met, in Portugal, by a rapid growth of land productivity. This is the outcome that many agrarian economists and economic historians would expect (Boserup 1969, Gadisseur 1973, Ruttan 1978, O’Brien and Toniolo 1986, Grantham 1989, Prados 1988, van Zanden 1991, Federico 1996). The role of demand in fostering agricultural output growth in Portugal is further confirmed by showing that there was a positive correlation between long run output and price trends (O’Brien 1985, Grantham 1989, Hunt and Pam 1997).

The paper proceeds as follows. Section 2 presents the new indices for agricultural output growth in the century to 1950, defines a periodisation of the evolution of agricultural output (1865-1902, 1902-27 and 1927-51) and sets Portugal's agricultural performance in an European perspective. Section 3 presents estimates for land and labour productivity growth and compares the productivity performance during the three periods defined in the previous section. Section 4 analyses the determinants of labour productivity growth in terms of hectare per labour and output per hectare; and the determinants of the evolution of output per hectare in terms of yields, product mix and demand for agricultural output. Finally, section 5 summarises our main conclusions on agricultural growth without major institutional changes. 


\section{Output trends and fluctuations}

Official data for Portugal's agricultural output date back to the 1840s, but it was only after 1915 that their publication became regular on a yearly basis. Official statistics include information on the output of the main crops, as well as land and livestock census. There is also information on agricultural output published in monographs, which provide further data on quantities of the main sectors, as well as estimates on total agricultural output and its composition. The data published in these monographs have a quasi-official character, as some of the authors were directly involved with government statistical boards and published information collected by government officials. Some of that data was not published with an official seal. ${ }^{1}$

Two annual indices based on the above data have been computed. The first index covers the period from 1848 to 1914 (Lains and Sousa 1998) and second covers the years from 1910 to 1958 (Batista et al. 1997). The index for the period to 1914 is computed from partial output indices for nine agricultural sectors, which accounted for over 80 per cent of total agricultural output throughout the period. The index for the later period covers output for 12 sectors which, by 1958, accounted for 83 per cent of total agricultural product. ${ }^{2}$ We have computed an index for the period from 1848 to 1958 based on partial indexes for nine sectors, linked in 1910 and aggregated according to the composition of gross output in 1900-9. Due to the fact that the structure of agricultural output did not change significantly until the 1930s, the choice of the base year is not of paramount relevance. ${ }^{3}$ The fact that the indices reflect the evolution of gross output and not value added may contribute for the overstatement of growth trends, particularly during the first half of the twentieth century, as a consequence of an eventual proportional increase in the use by agriculture of inputs from other sectors. Yet, that error is small because, as late as 1957/62, Portuguese agriculture only purchased 10 per cent 
of its gross output from other sectors (Hayami and Ruttan 1971, p. 320). Nineteenth century writers as well as agricultural historians have pointed out to the possibility that producers underreported output to government officials (Soares 1873, Pery 1875, Pereira 1915, Justino 1988-89). Most monographs that publish output estimates tend to add a parcel for underreported output, but the fact is that that parcel remains roughly constant across the various estimates. Thus, the trend of output derived from those estimates is similar to the one given by our index. Contemporary estimates also point out to the fact that the share of the sectors not included in our agricultural output index, namely, fruits and vegetables, dairy and wool remained relatively stable, except after $1930 .^{4}$

The fact that the information on which the index to 1914 is based is incomplete should be taken into account when analysing the resulting overall output trends and fluctuations. In the case of wheat output, there is only data for 52 out of the 70 years covered by the index, and for other cereals the coverage is still lower as there is data for only 34 years. For reasons that are related to the history of the collection of data by officials (Lains and Sousa, 1998), blanks in data occur mostly in the periods of 1874-81 and 1888-97. This implies that our index provides a good description of long term trends, as well as fluctuations, except for the mentioned periods. Thus, the major shortcoming of that index is that it may fail to detect peak years during the second half of the 1870s and during most of the 1890s. The index for 191058 is based on a more complete set of annual data after 1915 and it does not suffer from the same problems.

Graph 1 shows the long-term evolution of the index of agricultural output for 18481958. During the first decades shown in the graph there was a slight decline in output followed by a period of relative stagnation. As mentioned previously, the flat trend depicted by the index during the second half of the 1870 s is a consequence of the lack of data on cereal output. After 1880, agricultural output entered a phase of sustained growth that lasted until 
the beginning of the twentieth century. After the turn of the century, output declined and this depression lasted until the mid-1920s. Thereafter, output increased consistently, to the end of the period. Table 1 reports annual compound growth rates between the years when output peaked, namely, 1865, 1882, 1902, 1927 and $1951 .^{5}$

[graph 1; table 1]

Two periods of relatively high growth come out of table 1, namely, 1882-1902 and 1927-51, during which output expanded, respectively, at annual growth rates of 2.0 and 2.4 per cent. These periods of higher growth in Portuguese agriculture coincided with phases of higher industrial growth. Moreover, the agricultural sector expanded more rapidly than total GDP, due to the slower growth of the services sector. As a consequence of these trends, the share of agriculture in total output increased from 36 per cent, in 1880, to 42 per cent, in 1900. The agricultural share then declined to 31 per cent of GDP, in 1920, and remained roughly at that level until 1950 (Lains 1998).

Table 2 sets down the performance of Portugal's agricultural sector in an international context, during three periods between 1870 and 1930 for which Federico (2000) collected data. ${ }^{6}$ As shown there, during 1870-1913, Portugal's agricultural output trend growth rate was 1.2 per cent per year, which was slightly above the west and southern European average growth rates for the same period. Contrarily, the interwar output depression was felt less intensely in Portugal, as compared to most countries shown in the same table. Thus, during the 1920-38 period, Portuguese agriculture expanded at 3.8 per cent per year, which sets the sector among the fastest growing sectors in Europe.

[table 2] 


\section{Trends in productivity growth}

The availability of data on the growth of the use of inputs by Portuguese agriculture, namely, the use of land, labour force and capital, is rather limited. In fact, there is information only from agricultural land censuses or quasi-official estimates for 1867, 1902, 1920, 1929, 1939 and 1957; censuses for the composition of labour force for each decade after 1890; and censuses for livestock for 1870, 1906, 1925 and 1955. The available information on inputs coincides with our estimates for peak-to-peak growth rates, for the years from 1865-1902, 1902-27 and 1927-51, and our analysis of productivity growth will be restricted those periods. The analysis of productivity trends in this paper is also limited by the fact that the growth of livestock is a poor proxy for capital invested in agriculture, particularly after World War I, when mechanisation gained momentum. However, for the period after 1921, there is data concerning the proportion of cereal output threshed mechanically, which will be used as a proxy for the growth of the capital stock.

Table 3 depicts the evolution in the use of land, for which we have reliable information for census years in 1867, 1902 and 1957. As shown there, the area under crop increased sharply, from 21.2 per cent of total area, in 1867, to 34.9 per cent, in 1902 and remained roughly stable from 1902 to 1929. From 1929 to 1957, the area under crop increased again from 36.9 to 46.4 per cent of total area. ${ }^{7}$ All in all, there was a sharp decline in the area which was not put into agricultural use, from as much as 44.6 per cent of total area, in 1867, to just 7 per cent in 1959, although much of the fall was observed during the nineteenth century. The observed increase in the area under crop took place mainly in the wheat fields in southern Portugal after tariff and price protection was enhanced in two different periods, namely, in 1899 and 1929 (Reis 1993, ch. 2). According to Evangelista (1971, p. 220-1), that evolution is confirmed by the fact that, until the 1920s, population 
increased at higher speed in the South as compared to the rest of the country.

The two periods of expansion of the area under crop, mentioned above, differed in one important way. In the first period, between 1867 and 1902, the area under crop expanded mainly by putting into agricultural use land previously left idle. Thus, the area which was classified as 'unused but fit' by the censuses, declined from 44.6 per cent of the total area of the country, to 17.3 per cent (see table 3). After 1902 and, particularly, after 1929, the expansion of the area under crop was made possible by the contraction in the number of hectares of land left fallow and pasture, which declined by half between 1929 to 1957 . As a consequence of these different trends, total agricultural area, which includes area under crop, left fallow and pasture, increased by a significant margin, between 1867 and 1902, and then it remained relatively constant.

The land input is taken in this paper as total agricultural area, which includes area under crop, left fallow and pasture. The reason for that is that the agricultural output index presented in the previous section includes meat output and thus we have to take into account the area of permanent pasture. ${ }^{8}$ More importantly, we want to catch the effect of changes in rotation techniques and thus changes in the size of the area left fallow (O’Brien and Prados 1992, p. 517; Reis 1993, ch. 2).

[table 3]

Labour input is measured in terms of number of active male labour force employed in the agricultural sector, which is also the case for data with which Portugal is compared. We do not take into account female labour force, because of its erratic evolution in population census, during the interwar period. ${ }^{9}$ We also do not take into account changes in the number of hours worked, because we lack that information. It is probable that the number of worked hours per male increased as total output expanded (Bairoch 1989, p. 336). Thus our measure of the growth of labour force is underestimated and, consequently, the growth of labour 
productivity can be overestimated. The growth of output per male labour force catches changes in productivity of the existing labour force. (O’Brien and Prados, 1992, p. 527). Official population censuses provide data on active population employed in agriculture for each decade after 1890 (except for 1920). Contrarily, the only two previous population censuses, for 1864 and 1878, do not provide information on active population. As such, we use the number of males in the 20-59 age bracket, as a proxy for active male population. The use of this proxy implies the assumption that the proportion of males employed in agriculture remained constant, between 1864 and 1890, which is not too strong an assumption, given that structural change in the period was relatively slow. In fact, the ratio of males in the 20-59 age bracket in the total population, as well as the share of active male population, remained relatively constant in 1890, 1900 and 1911, at 68-69 per cent. Moreover, during the same decades, the ratio of agricultural labour force to total active population declined only slightly from 62 to 58 per cent. ${ }^{10}$ The data shows that there was a slight increase in total agricultural population, from 1864 to 1890, which was followed by a small decline in the decades to 1930 and a recovery thereafter. According to our estimates, labour force in agriculture expanded at 0.5 per cent per year between 1864 and 1900, declined in the interwar period, and expanded at 0.9 per cent per year between 1930 and 1950 (see table 4 below).

Table 4 sets down our main findings on land and labour productivity trends in the three periods from 1865 to 1951 . The table shows that agricultural land productivity increased throughout the century, although at a quicker pace after 1927. During the period from 18701910, the average growth rate of land productivity for 15 European countries was 0.9 per cent, close to the rate observed in Portugal, at 0.75 per cent (van Zanden 1991, tab. 4). Labour productivity increased at 0.9 per cent in the period from 1865-1902, as the rate of growth of labour force employed in agriculture increase at a smaller rate than agricultural output. In this respect, Portugal was above the van Zanden average for 15 countries, which was 0.6 per cent 
per year. During the following period, from 1902 to 1927, the rate of growth of output declined to 0.35 per cent. However, because the labour force in agriculture declined at -0.11 per cent per year, labour productivity increased at 0.46 . This was the worst period in terms of the growth of labour productivity and Portuguese agriculture clearly lost momentum in comparison to the agricultural sectors in Spain, France and Denmark, shown in table 4.

[table 4]

After 1927, Portuguese agricultural output expanded at a relatively rapid pace (2.36 per cent per year) and, despite the fact that labour force in agriculture also expanded more rapidly, labour productivity expanded at 1.45 per cent per year. This rate of growth was exceptional for Portugal, but below rates in similar periods in France and Denmark (see table 4). That difference was mainly due to the fact that Portuguese agricultural sector faced a sharp expansion in labour force, contrary to what happened in the other two countries and Spain during her period of rapid change prior to the Civil War (Simpson 1995, p. 28). ${ }^{11}$ It is worth noting that the fact that land input did not increase, during 1927-51, sets Portugal in line with what happened in the less developed economies in 1955-75 (Hayami and Ruttan 1971, pp. 71$72)^{12}$

Trends in the share of the agricultural population mirror those in the share of agricultural output in total GDP and thus there were no major changes in the sectorial productivity gap, except for a small increase from 1870 to 1890 and a small decline from 1930 to $1950 .{ }^{13}$ In 1850 , agricultural output accounted for 45.4 per cent of total output and the share declined in the following decades until 1880, to rise again in the period of growth from 1880 to 1900 . In 1900 , the agricultural sector accounted again for 41.5 per cent of total output. ${ }^{14}$ From 1900 to 1930 , Portugal's share of agricultural output declined from 41.5 to 33.1 per cent. Yet it remained constant in the two decades to 1950, in contrast to what happened in the other countries, such as Spain and Italy. The earlier structural transformation 
of Portugal's output was matched by a precocious shift of labour resources from agriculture to industry. In fact, at \$US 300 level of GDP per capita, Portugal had 57.8 per cent of its labour force employed in the agricultural sector, whereas the nineteenth century European norm for the same level was in the 69-73 per cent range, which compares to the correspondent World norm of 67 per cent. In 1950, with a level of GDP per capita of \$US 550, Portugal's labour share was still below the correspondent European and World norms. ${ }^{15}$

In order to estimate the growth of total factor productivity, we take coefficients for a Cobb-Douglas production function from van Zanden (1991) and Neves (1994). For the growth of capital stock in the agricultural sector we use two proxies. ${ }^{16}$ For the period to 1927 , we use the growth of livestock, standardized in terms of cattle units. For the period of increasing mechanization from 1927-51, we use a weighted average of the growth of livestock and cereal output threshed mechanically. Cereal output threshed mechanically increased by a factor of 4.4, from 28.5 per cent of total cereal output, in 1927, to 55.0 per cent, in 1951 . We assume that this is a good indicator of capital investment in the cereal production sector and that the growth of livestock is a good indicator for the rest of the agricultural sector. ${ }^{17}$ Taking the estimates on table 5, we conclude that TFP growth increased substantially in the period after 1927, from 0.33 per cent per year during 1902-27 to 1.62-1.66 per cent during 1927-51. There is not much scope for international comparison in this period as TFP estimates for other countries are scarce (see though Federico 2000). Yet factor productivity growth in Portugal during 1927-51 was well above any of the 15 European countries for which van Zanden (1991, tab. 4) provides data for the 1870-1910 period, where Denmark ranks first with an annual rate of growth of 1.3 per cent.

[table 5] 


\section{Explaining productivity growth}

The analysis of the determinants of total factor productivity growth through the estimation of a production function for the agricultural sector (McLean 1981) is out of the scope of this paper because we lack data on the use of land input, except for a few benchmark years, and data for agricultural investment other than livestock. Yet, total factor productivity growth must be imbedded in new techniques of production or in new capital invested in the agricultural sector (Hoffman 1996, p. 143).

The introduction of new techniques and capital can take two forms. One is through the use of more labour-intensive methods, which imply a more efficient use of land, water and animal resources, the intensification of the use of animal and chemical fertilisers, as well as shifts in the product mix towards sectors with higher levels of land productivity. Improved forms of management should also be included in this list. Alternatively, the introduction of new techniques can take the form of mechanisation in some steps of the production process. The relative importance of better production methods and agricultural mechanisation can be gauged by their impact on labour productivity. In fact, Hayami and Ruttan (1971, pp. 44-5) use a simple device to detect whether labour productivity growth results from changes in production methods and increasing use of fertilizers or from investment in machinery and other forms of capital. ${ }^{18}$ For that purpose, they decompose labour productivity $(\mathrm{O} / \mathrm{L})$ in terms of area per worker $(\mathrm{H} / \mathrm{L})$ and output per hectare $(\mathrm{O} / \mathrm{H})$, namely:

$$
\mathrm{O} / \mathrm{L}=\mathrm{H} / \mathrm{L} \times \mathrm{O} / \mathrm{H}
$$

or, taking exponential rates of growth $(\Delta)$ :

$$
\Delta(\mathrm{O} / \mathrm{L})=\Delta(\mathrm{H} / \mathrm{L})+\Delta(\mathrm{O} / \mathrm{H})
$$

The two different ways of introducing new techniques and capital, described above, have different effects in terms of changes in the relative use of inputs. If factor productivity 
increases through mechanisation, the process tends to be labour saving, because more machines 'usually requires a larger land area cultivated per worker' (Hayami and Ruttan, 1971, p. 44). In the case that higher total factor productivity derives from a better use of the existing resources, it is expected that there is an increase in output per unit of land and, consequently, it is mainly a land saving process.

The above analysis is necessarily a simplification of reality. In fact, new machinery can also promote the saving of land, as is the case, for example, of the seed drill, which improves the efficiency in the distribution of seed per unit of area (McLean 1981, p. 11). Moreover, the intensification in the use of machinery, as well as fertilizers, may also lead to the increase of the area under cultivation. If there is idle labour force, the new machinery can leave unchanged the land/labour ratio (Reis 1993, ch. 3; Simpson 1995, p. 6). Pereira and Estácio (1968, pp. 27-8) make also the point that the introduction of new machinery does not necessarily raise overall productivity levels if it leads to the substitution of crops with a lower value per hectare (such as wheat) for crops with a higher value per hectare (such as wine and pasture for livestock raising). Similarly, the reduction of fallow area may lead to the increase in labour productivity, without technical change, because of similar differences regarding the relative value of output.

Table 4 above shows the decomposition of the growth of labour productivity in terms of growth of the land/labour ratio and growth of output per hectare for Portugal and three other European countries. The first important feature to note from that table is that, in the case of Portugal, there is no close correlation between the rates of growth of output per worker, and the rate of growth of land per worker. In fact, during 1865-1902, output per worker increased at 0.9 per cent per year and land per worker also increased, although at a lower rate, namely at 0.15 per cent per year. In the following period, from 1902 to 1927, output per worker increased whereas land per worker declined. Finally, in the period from 1927-51, 
output per worker increased rapidly at 1.5 per cent per year, whereas land per worker declined, at -0.8 per cent per year. These trends indicate that there is no straightforward relationship between changes in labour productivity and changes in hectares per agricultural worker. On the contrary, there is a closer relationship between the growth of output per worker and the growth of output per hectare. ${ }^{19}$

According to Hayami and Ruttan, the increase in land per worker during the period from 1865 to 1902 should reflect an increase in use of machinery. This was partially true in the wheat fields of southern Portugal (Reis 1993, ch. 2). The increase in the number of livestock which can be observed in the same period (see table 5) may also have contributed to the increase in the land/labour ratio. Yet, we should also take into account the possibility that the increase in the number of hectares per agricultural worker also reflects a process of intensification of the use of labour force, through the expansion of the number of hours worked per labourer. From 1902 to 1927, the land/labour ratio remained virtually stagnant.

In the following decades, from 1927 to 1951, there was a significant decline in the number of hectares per agricultural worker, as the land/labour ratio declined at -0.8 per cent per year. During this period, there was also an important increase in output per hectare, suggesting a positive correlation between the number of workers per hectare and output per hectare. ${ }^{20}$ Table 4 reveals that Portugal and Spain were particular cases in this respect. In fact, in the two other countries for which data is shown in the table, namely France and Denmark, there was an increase in the number of hectares per agricultural worker in similar periods.

In other words, the Portuguese agricultural sector faced an increasing pressure of labour force in the land available for use, up to 1951. Yet that trend was met by an increase in output per unit of agricultural land, particularly in the 1927-51 period, when output per hectare expanded at an annual rate of 2.3 per cent. The increase in land productivity was ultimately reflected in the positive trend in labour productivity, during the same period. ${ }^{21}$ The 
study of the causes behind the increase in Portuguese agricultural labour productivity should thus concentrate on the analysis of the increase in output per unit of land.

The rise of land productivity can be explained in terms of an increase in yields or in terms of shifts in the product mix, in favour of sectors with higher value per unit of land (Robinson 1969, p. 29). The evolution of yields for the main crops, in the period from 1918 to 1954, is presented on table $6 .^{22}$ The data show an overall upward trend to $1930-34$, followed by a decline until 1945-49. This decline was mainly due to the sudden increase in the area under crop during World War II, in response the need to increase output of staples, namely wheat, potato and rye, in order to substitute for imports (Estatística Agrícola 1957, pp. 66-7). The expansion of the agricultural area in this period brought to production lands that were probably less fit for cereal cultivation (Pintado 1964, p. 82). There was a contemporary expansion in the use of chemical fertilizers but impact of that change was reduced because of its limited used. In fact, after a sharp decline following World War I, in the late 1930s Portuguese agriculture employed only $10 \mathrm{~kg} / \mathrm{ha}$ of chemical fertilizers, which trebled to 30 $\mathrm{kg} / \mathrm{ha}$ in the $1950 \mathrm{~s}^{23}$ Due to the decline in land productivity, during the war, the levels attained in 1945-49 were either below or only just similar to the levels in 1918-19 or 1920-24, with the exception of rice. Table 6 also shows the evolution of the weight of meat per animal slaughtered (in Lisbon and Oporto), which remained relatively stable throughout the same period. $^{24}$ The fact that yields evolved along a flat line, throughout 1918-19 to 1945-49 indicates that the growth of output per hectare in this period was mainly a consequence of shifts in the product mix, towards sectors with higher levels of land productivity. ${ }^{25}$

[table 6]

For lack of more recent estimates on land values with a high level of disegregation, table 7 shows relative average land values for 1900-9. It is improbable that these relative values changed significantly in the following decades. ${ }^{26}$ The data show that the relation 
between the value of land left fallow and that of land under oats, for example, is 1:4. This implies that bringing land left fallow into cultivation may have a large consequence in total land productivity (Chorley 1981). Even if that implies, as in our example, an increase in the cultivation of oats, which is the cereal with the lowest land value. The process of occupation of land left fallow occurred at a relatively high speed between 1927 and 1951, as shown in the previous section (see table 3 above). The differential in land values is even larger if we compare land under fruits and vegetables, and land under wheat, which also makes possible large increases of average land productivity by switching output to fruits and vegetables. ${ }^{27}$

[table 7]

Tables 8 and 9 show that there was an increase in the weight of the sectors with higher land. In fact, the weight of the output of fruits and vegetables in total agricultural output, in fact, increased from 6.5 per cent in 1935-9 to 12.7 per cent in 1954-8 (table 8). There was also an important increase in the share of animal output, from 28 per cent in 1935-9 to 35.9 per cent in 1954-8. There are no estimates for the correspondent change in land value, but it can be safely assumed that it is considerable. Table 9 shows that in the decades from 1930 to 1950, rice, potato and meat were the fastest growing sectors. Rice, potato, fruits and vegetables are more labour intensive than cereals and thus it explains the increase in labour force per unit of agricultural area.

[tables 8 and 9]

The increase in output in products such as potato and meat can be related to data on the expansion of consumption per capita. In fact, meat consumption per capita increased from $5.6 \mathrm{~kg}$, in $1916-25$ to $8.0 \mathrm{~kg}$, in $1936-45$, whereas potato consumption per capita increased from $31.6 \mathrm{~kg}$ to 83.3 , in the same period. The increase in consumption was met by domestic output, as foreign trade in these staples was negligible. Rice consumption per capita remained roughly constant (10 kg per capita), but there was an important shift from foreign to domestic 
sources, as net imports declined from twice the volume of domestic output, in 1916-25 to only 6.5 per cent in 1936-45..$^{28}$ These changes in the structure of domestic demand corresponded with shifts in the output mix and thus can be related to the observed increase in total land productivity.

Table 10 presents estimates for the growth of demand for agricultural output, based on the growth of income per capita, population, relative prices of agricultural produce, and three sets of price and income elasticities. According to the data shown in the table, the period after 1927 is clearly distinct from the precedent periods, in terms of growth of income per capita and population, as well as in terms of changes in relative prices. The trends in these three variables clearly favoured the increase in the rate of growth of demand for agricultural output, independently of the values for income and price elasticities. One conclusion we may derive from the estimates in table 10 is that agricultural output increased faster than demand, in the periods of fastest growth of agricultural output, namely, from 1865 to 1902 and from 1927 to 1951. In this latter period, output expanded at 2.4 per cent per year, which was slightly above the rate of growth of demand. During the period of higher growth from 1927-51, relative prices declined sharply, by -0.7 per cent per year, which indicates that agricultural supply was elastic in regard to prices. Thus, we may conclude, although not unambiguously, that the growth of demand prevailed in the determination of the growth of agricultural output. From the observation of a similar pattern in the case of France, Ruttan (1978, p. 718) has concluded that 'between 1880 and 1930 the "inefficient” French peasant provided the urban-industrial sector with more food per capita and at lower prices’.

[table 10]

The role of foreign demand for agricultural output should also be taken into account. Yet agricultural exports were only a small share of total output and thus the growth rates of demand estimated in table 10 would not change significantly (Lains 1986). Moreover, the 
evolution of the balance of foreign trade in agricultural products is compatible with the evolution of demand and supply depicted in table 10. In fact, before 1902, agricultural exports expanded rapidly (particularly to 1885), whereas after 1902, the trend in exports was reversed and imports of foodstuffs increased, particularly in the aftermath of World War I. The growth of wine exports, which was Portugal's main export item, was driven by the growth of demand, particularly in France, where vines had been severely affected by phylloxera. However, the fact was that there were important supply constraints too in regard to the adaptation of changing patterns of external demand for agricultural produce. For example, wine exports declined from the late 1880s onwards, as did cattle exports, because produce did not shift to other branches with higher elasticities of demand, contrary to what happened with Scandinavian exports (Lains, 1986 and 1995). Foreign demand for Portugal's agricultural output dwindled during the interwar period and did not recover thereafter and the role of domestic demand, including import substitution was thus paramount. It may be the case that the agricultural sector overall faced supply constraints, as did the export sector before 1913 . However, the fact that relative prices fell substantially during the period 1927-51, indicates that shifts in the demand curve for agricultural produce were more important than eventual shifts in the supply curve.

The understanding of productivity increases in Portugal's agricultural sector can only be tentative in the absence of estimates for a supply function. Such an estimate is not feasible at this stage for lack of yearly series, for most of the period, on the use of land, on capital and other inputs. However, we have established here that agricultural output expanded more rapidly in the two periods of higher demand growth and that it did so with declining relative prices of foodstuffs. This indicates agricultural supply to be elastic in relation to the increase in demand. It is a fact that the growth of demand for foodstuffs also depends on the growth of the agricultural sector, but the potential of that effect had declined substantially during the 
early decades of the twentieth century, due to the decline of the share of agricultural output in Portugal's national output (to 31 per cent during the 1930s and 1940s).

\section{Conclusions}

In this paper we have shown that Portugal's agricultural sector output and productivity expanded at a considerable pace for most of the period from 1850 to 1950 . Yet increases in output and productivity levels were obtained with no major institutional changes. In particular, there were no important transformations in the structure of land ownership and there were only slow developments in the introduction of new techniques and new forms of organization of production. Thus, new wine was put into old bottles. Truly, there were some important improvements in terms of uses of certain inputs as fertilizers, as well in infrastructures, from which the agricultural sector certainly took advantage. The development of the railway network, to the end of the nineteenth century, and the construction and improvement of roads, as well as of other means of communication, are examples of such favourable developments. Farmers also took benefit from the construction of municipal markets and slaughter houses, as well as from the institution of the first co-operatives, particularly after the turn of the century. The access to better information may also have improved, in the century after 1850, as schooling and technical assistance to farmers saw considerable development too. Yet, these developments were not sufficient to change the picture of extreme backwardness of Portugal's agricultural sector.

The fact that agricultural output and productivity growth in Portugal gained momentum in periods of expanding domestic demand, with stable or falling agricultural prices, led to the further conclusion that agricultural supply was elastic. The sector responded 
to market stimuli, which were felt in a stronger way in the years after 1930, due to the fact that the Portuguese economy entered a period of overall higher growth. The increase in the rate of growth of the agricultural and industrial sectors are intimately related, but the fact that agricultural prices did not increase in periods of agricultural expansion led to the conclusion that the limits of output expansion were linked to the slack growth of domestic demand for agricultural output. The role of external demand remained relatively unimportant throughout the century here analysed due to the fact that Portugal was not overall a competitive agricultural exporter, with few exceptions, until 1913 and to the fact that foreign markets were shut in the following decades. The fact that the growth of agricultural output was high, by European standards, implies that the achievements of the sector were probably close to its growth potential.

\section{References}

Andermann, G., H. Hockmann and G. Schmitt (1988). Historical changes in landlabour relationships in Western Europe. Journal of European Economic History 28, pp. 24583.

Bairoch, P. (1989). Les trois révolutions agricoles du monde développé : rendements et productivité de 1800 à 1985. Annales Économies Sociétés Cultures (March-April), pp. 31753.

Baptista, F. O. (1993). A Política Agrária do Estado Novo. Lisbon : Afrontamento.

Basto, E. A. L. (1936). Inquérito Económico Agrícola. Alguns Aspectos Económicos 
da Agricultura em Portugal Vol. 4. Lisbon: Universidade Técnica de Lisboa.

Batista, D., C. Martins, M. Pinheiro and J. Reis (1997). New estimates for Portugal’s GDP, 1910-58. História Económica 7.

Boserup. E. (1965). The Conditions of Agricultural Growth. Chicago: Aldine Publishing Company.

Caldas, E. C. (1957). Industrialização e agricultura. II Congresso dos Economistas Portugueses. Lisbon: Instituto Nacional de Estatística.

Carmona, J. and J. Simpson (1999). The 'Rabassa Morta' in Catalan viticulture: the rise and decline of a long-term sharecropping contract, 1670s-1920s. Journal of Economic History 59, pp. 290-315.

Castro, A. F. M. (1945). Alguns Aspectos da Agricultura Nacional. Coimbra: Coimbra Editora.

Chenery, H. and M. Syrquin (1975). Patterns of Development, 1950-70. Glasgow: Oxford University Press.

Chorley, G. P. H. (1981). The agricultural revolution in northern Europe, 1750-1880: nitrogen, legumes, and crop productivity. Economic History Review 34, pp. 71-93.

Crafts, N. F. R. (1980). Income elasticities of demand and the release of labour by agriculture during the British Industrial Revolution. Journal of European Economic History 9, pp. 153-68.

Crafts, N. F. R. (1984). Patterns of development in nineteenth century Europe. Oxford Economic Papers 34, pp. 438-58.

Crafts, N. F. R. (1985). British Economic Growth during the Industrial Revolution. Oxford: Claredon Press.

Dovring, F. (1956). Land and Labour in Europe, 1900-1950. The Hague: Martinus Nijhoff. 
Eddie, S. M. (1968). Agricultural production and output per worker in Hungary, 18701913. Journal of Economic History 18, pp. 197-222.

Estatística Agrícola (1947-1957). Lisboa: Instituto Nacional de Estatística.

Evangelista, J. (1971). Um Século de População Portuguesa, 1864-1960. Lisbon: Instituto Nacional de Estatística.

Federico, G. (1996). Italy, 1860-1940: a little-known success story. Economic History Review 49, pp. 764-86.

Federico, G. (2000). How did they feed us? The growth of world agricultural output, 1800-1938. Working Paper no. 203. Agricultural History Centre, University of California at Davis.

Fonseca, H. A. (1996). O Alentejo no Século XIX. Economia e Atitudes Económica. Lisbon: Imprensa Nacional.

Gadisseur, J. (1973). Contribution a l'étude de la production agricole en Belgique de 1846 à 1913. Revue Belge d'Histoire Contemporaine 4, pp. 1-48.

Gallego Martinez, D. (1986). Transformaciones técnicas de la agricultura española en el primer tercio del siglo XIX. In R. Garrabou, C. Barciela and J. I Jiménez Blanco (eds.) Historia Agraria de la España Contemporánea. 3 El Fin de la Agricultura Tradicional (19001960). Barcelona: Editorial Crítica, pp. 170-229.

Girão, J. A. (1980). Natureza do Problema Agrícola em Portugal (1950-73). Oeiras: Instituto Gulbenkian de Ciência.

Gomes, M. de A. (1920). A Situação Económica da Agricultura Portuguesa. Lisbon: Museu Comercial.

Gomes, M. de A., H. de Barros and E. de C. Caldas (1944). Traços principais da evolução da agricultura portuguesa entre as duas guerras mundiais. Revista do Centro de Estudos Económicos 1, pp. 21-203. 
Grantham, G. (1989). Agricultural supply during the Industrial Revolution: French evidence and European implications. Journal of Economic History 49, pp. 43-72.

Hayami, Y. and V. W. Ruttan (1971). Agricultural Development: An International Perspective. Baltimore: The Johns Hopkins Press.

Hoffman, P. T. (1996). Growth in a Traditional Society. The French Countryside, 1450-1815. Princeton (N.J.): Princeton University Press.

Hunt, E. H. and S. J. Pam (1997). Prices and structural response in English agriculture, 1873-1896. Economic History Review 50, pp. 477-505.

Hunt, E. H. and S. J. Pam (2001). Managerial failure in late Victorian Britain?: land use and English agriculture. Economic History Review 54, pp. 240-66.

Justino, D. (1988-89). A Formação do Espaço Económico Nacional. Portugal, 18101913 (2 vols.). Lisbon: Vega.

Justino, D. (1991). Índice de preços e salários em Portugal. História Económica 3.

Kostrowicka, I. (1984). Changes in agricultural productivity in the kingdom of Poland in the nineteenth and early twentieth centuries. Journal of European Economic History 13, pp. 75-97.

Lains, P. (1986). Exportações portuguesas, 1850-1913: a tese da dependência revisitada. Análise Social 22, pp. 381-419.

Lains, P. (1990). A evolução da agricultura e da indústria em Portugal, 1850-1913. Uma interpretação quantitativa. História Económica 1.

Lains, P. (1994). O Estado e a industrialização em Portugal, 1945-1990. Análise Social 29, pp. 923-58.

Lains, P. (1995) A Economia Portuguesa no Século XIX. Crescimento Económico e Comércio Externo, 1851-1913. Lisbon: Imprensa Nacional (French ed. L’Harmattan, 1999). Lains, P. (1998). Sources of growth and stagnation of the Portuguese agriculture, 
1850-1950. Paper presented at the Workshop on Agricultural Change in Southern Europe in the Nineteenth Century, European University Institute, Florence.

Lains, P. (2002). Southern European economic backwardness revisited: the role of open economy forces in Portugal and the Balkans, 1870-1913. Scandinavian Economic History Review 50, pp. 24-43.

Lains, P. and P. Sousa (1998). Estatística e produção agrícola em Portugal, 18481914, Análise Social, 33, pp. 935-68.

McLean, I. W. (1981). The analysis of agricultural productivity: alternative views and Victorian evidence. Australian Economic History Review 21, pp. 6-28.

Mitchell, B. R. (1996), International Historical Statistics. Europe, 1750-1988. London: MacMillan.

Molinas, C. and L. Prados de la Escosura (1989). Was Spain different? Spanish historical backwardness revisited. Explorations in Economic History 26, pp. 385-402.

Moore, W. M. (1945). Economic Demography of Eastern and Southern Europe. Geneva: League of Nations.

Morilla Critz, J., A. L. Olmstead and P. W. Rhode (1999). 'Horne of plenty': the globalization of Mediterranean horticulture and the economic development of southern Europe, 1880-1930. Journal of Economic History 59, pp. 316-52.

Neves, J. C. das (1994). The Portuguese Economy. A Picture in Figures. XIX and XX Centuries. Lisbon: Universidade Católica Editora.

Nunes, A. B. (1991). A evolução da estrutura, por sexos, da população activa em Portugal - um indicador do crescimento económico, 1890-1981. Análise Social 26, pp. 70722.

O’Brien, P. K. (1985). Agriculture and the home market for English industry, 16601820. English Historical Review 100, pp. 773-88.

O’Brien, P. K. and C. Keyder (1978). Economic Growth in Britain and France, 1780- 
1914. Two Paths to the Twentieth Century. London: George Allen \& Unwin.

O’Brien, P. K. and G. Toniolo (1986). Sull'arretratezza dell'agricoltura italiana rispetto a quella del Regno Unito attorno al 1910. Ricerche Economiche 40, pp. 266-85.

O’Brien, P. K. and L. Prados (1992). Agricultural productivity and European industrialisation, 1890-1980. Economic History Review 45, pp. 514-36.

Pereira, J. C. (1915). Economia e Finanças. A Propriedade Rústica em Portugal. Lisbon: Imprensa Nacional.

Pereira, M. and F. Estácio (1968). Produtividades do Trabalho e da Terra no Continente. Oeiras: Fundação Calouste Gulbenkian.

Pery, G. (1875). Geografia e Estatística Geral de Portugal e Colónias, Lisbon.

Pintado, X. (1964). Structure and Growth of the Portuguese Economy. Geneva: EFTA.

Prados de la Escosura, L. (1988). De Império a Nación. Crecimiento y Atraso Económico en Espana, 1780-1930. Madrid: Alianza.

Presidência do Conselho (1969). III Plano de Fomento para 1968-1973. Lisbon: Imprensa Nacional.

Reis, J. (1993). O Atraso Económico Português em Perspectiva Histórica, 1850-1930. Lisbon: Imprensa Nacional.

Robinson, E. A. G. (1969). The desirable level of agriculture in the advanced industrial economies. In U. Papi and C. Nunn (eds.) Economic Problems in Agriculture in Industrial Societies. London: Macmillan, pp. 26-44.

Ruttan, V. W. (1978). Structural retardation and the modernisation of French agriculture: a sceptical view. Journal of Economic History 38, pp. 714-28.

Sanz, Jesús (1994). La agricultura española durante el primer tercio del siglo XX: un sector en transformación. In J. Nadal, A. Carreras and C. Sudrià (eds.) La economía española 
en el siglo XX. Una perspectiva histórica. Madrid: Ariel, pp. 239-57

Silva, F. M. (1970). O Povoamento da Metrópole Através dos Censos. Lisbon: Instituto Nacional de Estatística.

Simpson, J. (1995), Spanish Agriculture. The Long Siesta, 1765-1965, Cambridge: Cambridge University Press.

Soares, F. B. (1985). Portuguese EEC integration: some prospective effects upon the agricultural sector. In F. B. Soares (ed.) Prospective Evolution of EEC Common Agricultural Policy: its Relevance for Mediterranean Members. Oeiras: Instituto Gulbenkian de Ciência, 1985, pp. 71-93.

Soares, R. M. (1873). Relatório da Direcção Geral de Comércio e Indústria. Lisbon: Imprensa Nacional.

Toutain, J.-C. (1992). La production agricole de la France de 1810 a 1990: Départements et régions. Croissances, productivité, structures. Economies et sociétés 11-12, pp. 1-335.

Valério, N. (1984). A Moeda em Portugal, 1913-1947. Lisbon: Sá da Costa.

Van Zanden, J. L. (1991). The first green revolution: the growth of production and productivity in European agriculture, 1870-1914. Economic History Review 44, pp. 215-39.

Zamagni, V. (1993). The Economic History of Italy, 1860-1990. Oxford: Claredon Press. 
Table 1 - Growth of agricultural output (annual peak to peak growth rates, per cent)

\begin{tabular}{|c|c|}
\hline $\mathbf{1 8 4 8 - 1 8 6 5}$ & -0.56 \\
$\mathbf{1 8 6 5 - 1 8 8 2}$ & 0.76 \\
$\mathbf{1 8 8 2 - 1 9 0 2}$ & 1.97 \\
$\mathbf{1 9 0 2 - 1 9 2 7}$ & 0.35 \\
$\mathbf{1 9 2 7 - 1 9 5 1}$ & 2.36 \\
\hline
\end{tabular}

Source: Appendix table.

Table 2 - Growth of agricultural production in Europe (annual trend growth rates; per cent)

\begin{tabular}{|l|ccc|c|}
\hline & $\mathbf{1 8 7 0 - 1 9 1 3}$ & $\mathbf{1 9 1 3 - 1 9 2 0}$ & $\mathbf{1 9 2 0 - 1 9 3 8}$ & $\mathbf{1 8 7 0 - 1 9 3 8}$ \\
\hline Austria & 1.44 & -3.55 & 2.06 & 1.09 \\
Hungary & 2.72 & -1.90 & 0.88 & 1.79 \\
Belgium & 0.70 & -0.57 & 1.60 & 0.61 \\
Denmark & 1.62 & -0.60 & 3.46 & 1.93 \\
France & 0.62 & -0.66 & 1.13 & 0.69 \\
Germany & 1.56 & -4.32 & 3.11 & 0.91 \\
Greece & 2.12 & -5.90 & 4.27 & 1.53 \\
Italy & 0.86 & -0.27 & 0.29 & 0.82 \\
Netherlands & 0.86 & 1.69 & 1.96 & 0.68 \\
Portugal & $\mathbf{1 . 1 9}$ & $\mathbf{- 1 . 5 6}$ & $\mathbf{3 . 8 3}$ & $\mathbf{0 . 8 6}$ \\
Spain & 0.76 & 1.41 & 0.77 & 0.97 \\
Sweden & 1.62 & -2.64 & 3.01 & 1.14 \\
UK & 0.00 & -0.74 & 1.87 & 0.26 \\
\hline W. European average ${ }^{2}$ & 0.96 & -2.09 & 1.08 & 0.75 \\
S. European average $^{3}$ & 0.87 & 0.19 & 0.76 & 0.89 \\
\hline
\end{tabular}

${ }^{1}$ Geometric growth rates for $1911 / 13$ to $1920 / 22$.

${ }^{2}$ UK, France, Sweden, Denmark, Belgium, Netherlands, Germany and Finland.

${ }^{3}$ Italy, Greece, Spain and Portugal.

Source: Federico (2000)

Table 3 - Land use, 1867-1957 


\begin{tabular}{|l|cc|cc|cc|cc|}
\hline & \multicolumn{2}{|c|}{1867} & \multicolumn{2}{c|}{1902} & \multicolumn{2}{c|}{1929} & \multicolumn{2}{c|}{1957} \\
\hline & 000 ha & $\%$ & 000 ha & $\%$ & 000 ha & $\%$ & 000 ha & $\%$ \\
\hline 1. Under crop & 1,886 & 21.2 & 3,111 & 34.9 & 3,283 & 36.9 & 4,130 & 46.4 \\
2. Fallow and pasture & 2,116 & 23.8 & 1,926 & 21.7 & 1,565 & 17.6 & 810 & 9.1 \\
\hline 3. Agricultural (1+2) & 4,002 & 44.9 & 5,037 & 56.6 & 4,848 & 54.4 & 4,940 & 55.5 \\
4. Forests & 640 & 7.2 & 1,957 & 22.0 & 2,332 & 26.2 & 2,500 & 28.1 \\
\hline 5. Productive (3+4) & 4,642 & 52.1 & 6,994 & 78.5 & 7,180 & 80.6 & 7,440 & 83.5 \\
6. Unused but fit & 3,973 & 44.6 & 1,538 & 17.3 & 1,353 & 15.2 & 624 & 7.0 \\
7. Unfit & 291 & 3.3 & 374 & 4.2 & 373 & 4.2 & 842 & 9.5 \\
\hline Total (5+6+7) & 8,906 & 100 & 8,906 & 100 & 8,906 & 100 & 8,906 & 100 \\
\hline
\end{tabular}

Notes: The 1867 Census does not include the area under thickets (matas). The area 'unused and fit' for 1902 and 1929 is taken from Gomes et al., and the unfit area is deduced from the total. The extension of unfit area was redefined in the 1957 Census. The years in the table are those of the date of publication of the censuses.

Sources: Estatística Agrícola (1957, p. 1) and Gomes et al. (1944, p. 73).

Table 4 - Growth of agricultural output, inputs and productivity:

Portugal, Spain, France and Denmark

(annual growth rates, per cent)

\begin{tabular}{|c|c|c|cc|ccc|}
\hline & Period & Output & Land & $\begin{array}{c}\text { Labour } \\
\text { force }\end{array}$ & $\begin{array}{c}\text { Output } \\
\text { per } \\
\text { worker }\end{array}$ & $\begin{array}{c}\text { Land per } \\
\text { worker }\end{array}$ & $\begin{array}{c}\text { Output } \\
\text { per ha }\end{array}$ \\
\hline & & $\Delta \mathrm{O}$ & $\Delta \mathrm{H}$ & $\Delta \mathrm{L}$ & $\Delta(\mathrm{O} / \mathrm{L})$ & $\Delta(\mathrm{H} / \mathrm{L})$ & $\Delta(\mathrm{O} / \mathrm{H})$ \\
\hline \multirow{3}{*}{ Portugal } & $1865-1902$ & 1.41 & 0.66 & 0.51 & 0.90 & 0.15 & 0.75 \\
& $1902-1927$ & 0.35 & -0.14 & -0.11 & 0.46 & -0.03 & 0.49 \\
& $1927-1951$ & 2.36 & 0.07 & 0.91 & 1.45 & -0.84 & 2.29 \\
\hline \multirow{3}{*}{ Spain } & $1891 / 95-1909 / 13$ & 0.65 & 0.64 & 0.83 & -0.18 & -0.19 & 0.01 \\
& $1909 / 13-1929 / 33$ & 1.23 & 0.31 & -1.00 & 2.23 & 1.31 & 0.92 \\
& $1929 / 33-1949 / 51$ & -0.26 & -0.28 & 1.28 & -1.54 & -1.00 & 0.02 \\
\hline \multirow{3}{*}{ France } & $1860-1890$ & 0.30 & 0.08 & -0.30 & 0.60 & 0.38 & 0.22 \\
& $1890-1930$ & 0.70 & -0.09 & -0.55 & 1.25 & 0.64 & 0.79 \\
& $1930-1950$ & 0.75 & 0.00 & -1.75 & 2.50 & 1.75 & 0.75 \\
\hline \multirow{2}{*}{ Denmark } & $1860-1930$ & 2.07 & 0.24 & 0.41 & 1.66 & -0.17 & 1.83 \\
& $1930-1960$ & 1.39 & -0.14 & -0.90 & 2.29 & 0.76 & 1.53 \\
\hline
\end{tabular}

Notes and sources: Data for Portugal as follows: output from table 1; agricultural area from table 3; labour force is male labour force in agriculture in 1900, 1930 and 1950 from Silva (1970, pp. 170-71), and males in the 20-59 years bracket from Silva (1970, p. 115) (see also text). Data for Spain and France are from Simpson (1995, pp. 26 and 29) and Toutain (1992, pp. 14, 19 and 51). For France the area is area under crop (territoire cultivé). See also Ruttan (1978, p. 723) and Andermann et al. (1998, p. 249). 
Table 5 - Total factor productivity growth in Portugal

(annual growth rates, per cent)

\begin{tabular}{|c|c|c|c|c|c|c|c|c|c|c|c|}
\hline & & & Land & & & Labour & & & Capita & & TFP \\
\hline & growth & growth & share & d & growth & share & g & growth & share & $\mathrm{j}$ & $\mathrm{k}$ \\
\hline & $\mathrm{a}$ & $\mathrm{b}$ & $\mathrm{C}$ & $\begin{array}{c}= \\
\mathrm{b} \times \mathrm{c}\end{array}$ & $\mathrm{E}$ & $\mathrm{f}$ & $\begin{array}{c}= \\
\text { exf }\end{array}$ & $\mathrm{h}$ & $\mathrm{i}$ & $\begin{array}{c}= \\
\text { hxi }\end{array}$ & $\begin{array}{c}= \\
a-d-g-j\end{array}$ \\
\hline 1865-1902 & 1.41 & 0.66 & 0.35 & 0.23 & 0.51 & 0.50 & 0.26 & 0.63 & 0.15 & 0.09 & 0.83 \\
\hline 1902-1927 & 0.35 & -0.14 & 0.35 & -0.05 & -0.11 & 0.50 & -0.06 & 0.86 & 0.15 & 0.13 & 0.33 \\
\hline 1927-1951 I & 2.36 & 0.07 & 0.35 & 0.02 & 0.91 & 0.50 & 0.46 & 1.44 & 0.15 & 0.22 & 1.66 \\
\hline 1927-1951 II & 2.36 & 0.07 & 0.35 & 0.02 & 0.91 & 0.40 & 0.36 & 1.44 & 0.25 & 0.36 & 1.62 \\
\hline
\end{tabular}

Notes and sources: Growth rates for output, land and labour from table 4. All figures are three-year averages, centered in the years indicated.

The rate of growth for capital is taken as the growth of animal stock standardized as follows: 1 cattle unit $=6$ pigs, and 15 goats and sheep. The totals are (in thousands): $1870=1,159 ; 1906=1,452 ; 1925=$ 1,708; 1955 =1,845. Data from Justino (1988-89 Vol. 2, p. 276) and Mitchell (1992, p. 355). The growth of livestock after 1927 falls below estimates for growth of meat output from Batista et al. (1997) (see Appendix table), which is due to the increasing share in the meat production stock.

Capital stock growth for 1927-51 is based on a weighted average of the annual growth of cereal output threshed mechanically (6.39\%) and growth of livestock (0.26\%), using shares in total output for 195458 for cereals (0.192) and all other products (0.808). Data from Estatística Agrícola (1945, p. 105; 1951, p. 170; and 1953, p. 198) and from table 8 for the shares.

Factor shares are from van Zanden (1991, p. 219n), except for 1927-51, row II, which are based on data for 1958 from Neves (1994, p. 72) (assuming that the land share is also 35\%). See also Crafts (1985, pp. 78-84) and Lains (1990).

Table 6 - Productivity of main crops and meat production, 1918-1954

(output per hectare and average weight of cattle; 1953=100)

\begin{tabular}{|c|cccccc|}
\hline & Wheat & Maize & Rye & Rice & Potato & Meat \\
\hline $\mathbf{1 9 1 8 - 2 0}$ & 63.8 & 104.4 & 74.4 & 44.7 & 94.2 & 94.3 \\
$\mathbf{1 9 2 0 - 2 4}$ & 75.2 & 120.7 & 91.2 & 48.4 & 106.5 & 104.1 \\
$\mathbf{1 9 2 5}-29$ & 70.4 & 134.7 & 97.3 & 46.2 & 136.7 & 103.3 \\
$\mathbf{1 9 3 0 - 3 4}$ & 110.2 & 119.0 & 113.8 & 56.8 & 156.4 & 100.6 \\
$\mathbf{1 9 3 5}-39$ & 96.1 & 104.7 & 109.0 & 77.9 & 144.5 & 97.7 \\
$\mathbf{1 9 4 0 - 4 4}$ & 72.8 & 119.4 & 96.8 & 77.1 & 117.2 & 96.8 \\
$\mathbf{1 9 4 5 - 4 9}$ & 62.6 & 84.8 & 73.5 & 77.1 & 80.0 & 101.9 \\
$\mathbf{1 9 5 0 - 5 4}$ & 97.2 & 121.3 & 101.2 & 103.8 & 102.3 & 102.4 \\
\hline
\end{tabular}

Source:. Computed from Estatística Agrícola, 1957, pp. 66-67 and 139.

Table 7 - Land values, 1900-09 


\begin{tabular}{|l|cc|c|}
\hline & $\begin{array}{c}\text { Cultivated } \\
\text { area } \\
000 \text { ha }\end{array}$ & $\begin{array}{c}\text { Value of } \\
\text { land } \\
000 \text { contos }\end{array}$ & $\begin{array}{c}\text { Value per } \\
\text { hectare } \\
\$ / \text { ha }\end{array}$ \\
\hline Fruits and vegetables & na & na & 1,277 \\
Rice & 8 & 8.0 & 1,000 \\
Vine & 345 & 339.0 & 983 \\
Potato & 50 & 43.5 & 870 \\
Maize & 355 & 259.3 & 730 \\
Wheat & 340 & 167.7 & 493 \\
Under crop & $\mathbf{4 , 4 2 8}$ & $\mathbf{1 , 3 9 0}$ & $\mathbf{3 1 4}$ \\
Olive trees & 329 & 100.0 & 304 \\
Rye & 200 & 47.5 & 238 \\
Agricultural area & $\mathbf{6 , 4 2 8}$ & $\mathbf{1 , 4 7 2}$ & $\mathbf{2 2 9}$ \\
Barley & 140 & 28.0 & 200 \\
Cork trees & 475 & 95.0 & 200 \\
Oat & 100 & 16.3 & 163 \\
Other forest & 2,086 & 286.1 & 137 \\
Fallow land & $\mathbf{2 , 0 0 0}$ & $\mathbf{8 2 . 0}$ & $\mathbf{4 1}$ \\
\hline
\end{tabular}

Note: definitions of area under crop and agricultural area according to table 3.

Source: Pereira (1915, pp. 123, 231 and 334).

Table 8 - The structure of agricultural output, 1853-1958

(current prices; per cent)

\begin{tabular}{|c|c|c|c|c|}
\hline & $1861-70$ & $1900-9$ & 1935-39 & 1954-58 \\
\hline Cereals and potatoes & 38.9 & 35.4 & 40.6 & 27.3 \\
\hline Wheat & 10.8 & 11.0 & 17.5 & 19.2 \\
\hline Other cereals & 23.6 & 19.9 & 14.0 & $a$ \\
\hline Potatoes & 4.5 & 4.5 & 9.1 & 8.1 \\
\hline Wine & 21.8 & 23.3 & 13.5 & 12.7 \\
\hline Olive oil & 5.8 & 8.1 & 7.9 & 6.6 \\
\hline Fruits and vegetables & 7.8 & 6.5 & 6.5 & 12.7 \\
\hline Animal products & 24.8 & 23.1 & 28.0 & 35.9 \\
\hline Meat & 15.3 & 16.2 & 18.7 & 23.4 \\
\hline Dairy & 7.5 & 5.6 & 7.8 & 10.2 \\
\hline Wool & 2.2 & 0.8 & 1.5 & 2.3 \\
\hline Cork & 0.7 & 3.8 & 3.2 & 4.8 \\
\hline TOTAL & 100 & 100 & 100 & 100 \\
\hline
\end{tabular}

${ }^{\mathrm{a}}$ Included in wheat

Sources: Lains (1995, table A.13), Gomes et al. (1944, pp. 129-31) and Presidência do Conselho (1969, p. 540). 
Table 9 - Agricultural sectorial growth (annual growth rates; per cent)

\begin{tabular}{|l|ccccccccc|c|}
\hline & Wheat & Maize & Rye & Rice & Potato & Wine & $\begin{array}{c}\text { Olive } \\
\text { oil }\end{array}$ & Meat & Cork & Total \\
\hline $\mathbf{1 8 7 0 - 1 9 0 0}$ & 1.10 & 0.48 & 1.89 & -1.87 & 1.41 & 3.49 & 2.60 & 0.85 & 2.30 & 1.62 \\
$\mathbf{1 9 0 0 - 1 9 3 0}$ & 1.83 & -1.11 & -1.06 & 3.11 & 3.25 & -0.61 & -0.01 & 0.57 & 2.73 & 0.55 \\
$\mathbf{1 9 3 0 - 1 9 5 0}$ & 2.10 & -0.04 & 1.73 & 8.09 & 4.01 & 1.41 & 2.11 & 2.61 & 3.11 & 2.45 \\
\hline
\end{tabular}

Source: computed from the Appendix table.

Table 10 - Agricultural demand and output growth (annual growth rates; per cent)

\begin{tabular}{|l|c|c|c|ccc|c|}
\hline & GDP pc & $\begin{array}{c}\text { Relative } \\
\text { prices }\end{array}$ & Population & \multicolumn{3}{|c|}{ Demand } & $\begin{array}{c}\text { Agricultural } \\
\text { output }\end{array}$ \\
\hline & $\mathrm{Y}$ & $\mathrm{R}$ & $\mathrm{P}$ & $\mathrm{D} 1$ & $\mathrm{D} 2$ & $\mathrm{D} 3$ & $\mathrm{O}$ \\
\hline & & & & $\mathrm{n}=0.7$ & $\mathrm{n}=0.6$ & $\mathrm{n}=0.48$ & \\
& & & & $\mathrm{e}=-0.5$ & $\mathrm{e}=-0.3$ & $\mathrm{e}=-0.31$ & \\
\hline $\mathbf{1 8 6 5 - 1 9 0 2}$ & 0.59 & 0.09 & 0.74 & 1.11 & 1.07 & 1.00 & 1.41 \\
$\mathbf{1 9 0 2 - 1 9 2 7}$ & 0.91 & -0.43 & 0.69 & 1.54 & 1.37 & 1.26 & 0.35 \\
$\mathbf{1 9 2 7 - 1 9 5 1}$ & 1.38 & -0.86 & 1.08 & 2.48 & 2.17 & 2.01 & 2.36 \\
\hline
\end{tabular}

Notes and sources:

Demand for agriculture is estimated according to the following equation:

$\mathrm{D}=\mathrm{n} . \mathrm{Y}+\mathrm{e} . \mathrm{R}+\mathrm{P}$ (see Crafts 1980).

Income (n) and price elasticities (e) of demand are from: D1 - Prados (1988, p. 111), for Spain in 1800-1910; D2 - Ruttan (1978, p. 717n) higher bound for the United States, in 1929-56; D3 - Soares (1985, pp. 80-1) for Portugal, in 1979-80.

GDP per capita and population growth is from Lains (1998); relative price foodstuffs/general (R) is from Appendix table; and agricultural output growth is from table 1. 
Appendix table

Indices of agricultural output growth and prices, 1848-1957

$(1900=100)$

\begin{tabular}{|c|c|c|c|c|c|c|c|c|c|c|c|c|}
\hline & \multicolumn{10}{|c|}{ Output growth } & \multicolumn{2}{|c|}{ Prices } \\
\hline & Wheat & Maize & Rye & Rice & $\begin{array}{c}\text { Pota- } \\
\text { toes }\end{array}$ & Wine & $\begin{array}{c}\text { Olive } \\
\text { oil }\end{array}$ & Meat & Cork & Total & $\begin{array}{c}\text { Food } \\
\text { stuffs }\end{array}$ & Total \\
\hline 1848 & 101.6 & 72.1 & 76.5 & 77.2 & 114.7 & 73.2 & 63.6 & 87.1 & 13.1 & 78.1 & -- & -- \\
\hline 1849 & 87.5 & 71.1 & 72.1 & 61.1 & 86.0 & 48.4 & 33.5 & 87.1 & 14.1 & 64.8 & -- & -- \\
\hline 1850 & 75.4 & 76.8 & 58.0 & 75.0 & 60.7 & 50.5 & 50.0 & 87.1 & 15.3 & 64.3 & 56.7 & 57.6 \\
\hline 1851 & 103.1 & 67.5 & 82.7 & 81.9 & 52.0 & 59.7 & 92.4 & 87.1 & 16.5 & 74.0 & 53.1 & 54.1 \\
\hline 1852 & 112.3 & 68.5 & 94.5 & 81.3 & 77.3 & 47.7 & 41.1 & 87.0 & 16.5 & 69.3 & 50.9 & 52.2 \\
\hline 1853 & 91.8 & 78.8 & 68.3 & 102.6 & 76.7 & 51.9 & 43.2 & 84.4 & 16.5 & 67.7 & 60.2 & 61.0 \\
\hline 1854 & 115.2 & 56.9 & 72.4 & 108.8 & 75.3 & 34.1 & 52.1 & 81.9 & 16.5 & 63.0 & 75.3 & 75.5 \\
\hline 1855 & 97.2 & 83.6 & 93.6 & 75.4 & 74.7 & 33.2 & 247.5 & 79.5 & 16.5 & 83.7 & 79.1 & 79.3 \\
\hline 1856 & 36.7 & 84.0 & 44.0 & 106.2 & 73.7 & 11.6 & 145.8 & 77.1 & 21.8 & 57.6 & 93.1 & 92.8 \\
\hline 1857 & 109.8 & 91.6 & 89.6 & 110.3 & 76.0 & 10.4 & 97.5 & 74.8 & 22.8 & 65.8 & 91.5 & 91.6 \\
\hline 1858 & 69.4 & 65.4 & 77.0 & 83.6 & 78.0 & 28.9 & 91.9 & 72.6 & 23.9 & 59.7 & 78.0 & 79.0 \\
\hline 1859 & 73.7 & 90.8 & 65.4 & 99.3 & 80.0 & 11.4 & 62.3 & 70.5 & 25.0 & 56.0 & 82.1 & 82.6 \\
\hline 1860 & 88.1 & 83.7 & 72.5 & 81.5 & 82.0 & 13.2 & 75.8 & 68.4 & 26.2 & 58.5 & 81.5 & 81.9 \\
\hline 1861 & 86.3 & 84.0 & 70.5 & 108.7 & 84.0 & 19.6 & 64.8 & 65.9 & 27.4 & 58.8 & 82.3 & 83.0 \\
\hline 1862 & 65.3 & 69.5 & 66.4 & 127.7 & 86.0 & 23.8 & 152.5 & 73.3 & 28.6 & 64.6 & 84.2 & 85.7 \\
\hline 1863 & 71.3 & 71.9 & 68.7 & 120.1 & 77.3 & 23.4 & 33.4 & 66.5 & 29.9 & 52.9 & 81.6 & 84.6 \\
\hline 1864 & 77.8 & 74.4 & 71.0 & 113.4 & 78.0 & 23.1 & 40.2 & 72.6 & 31.2 & 56.0 & 82.2 & 85.2 \\
\hline 1865 & 84.9 & 77.0 & 73.3 & 107.7 & 80.7 & 22.7 & 191.1 & 69.3 & 32.6 & 71.1 & 78.3 & 81.0 \\
\hline 1866 & 87.0 & 81.8 & 80.9 & 109.7 & 81.3 & 22.4 & 112.6 & 73.8 & 34.0 & 66.1 & 80.9 & 84.2 \\
\hline 1867 & 89.2 & 86.9 & 89.2 & 111.9 & 82.7 & 27.5 & 75.3 & 77.2 & 39.0 & 66.4 & 85.1 & 86.9 \\
\hline 1868 & 83.2 & 88.0 & 67.6 & 142.9 & 86.0 & 33.6 & 68.2 & 76.4 & 38.4 & 65.7 & 83.6 & 84.9 \\
\hline 1869 & 77.6 & 89.1 & 51.2 & 204.9 & 90.0 & 35.1 & 47.0 & 84.3 & 41.2 & 64.8 & 77.9 & 80.3 \\
\hline 1870 & 81.4 & 87.7 & 57.3 & 176.1 & 83.3 & 35.5 & 80.9 & 81.0 & 66.5 & 68.7 & 76.1 & 78.2 \\
\hline 1871 & 85.5 & 86.4 & 64.1 & 151.5 & 77.3 & 35.9 & 79.2 & 61.0 & 43.2 & 64.2 & 75.0 & 76.5 \\
\hline 1872 & 89.9 & 85.1 & 71.8 & 130.6 & 72.0 & 27.7 & 117.8 & 58.7 & 53.5 & 66.0 & 76.2 & 78.6 \\
\hline 1873 & 94.4 & 83.8 & 80.3 & 111.9 & 66.7 & 35.4 & 54.2 & 63.6 & 57.3 & 63.6 & 75.9 & 78.6 \\
\hline 1874 & 94.1 & 81.6 & 79.9 & 107.5 & 100.0 & 36.4 & 63.6 & 64.7 & 68.9 & 66.7 & 78.9 & 81.5 \\
\hline 1875 & 93.8 & 79.5 & 79.5 & 103.0 & 100.0 & 37.3 & 63.6 & 76.4 & 48.7 & 67.9 & 80.8 & 82.9 \\
\hline 1876 & 93.4 & 77.4 & 79.1 & 105.2 & 100.0 & 38.3 & 63.6 & 75.5 & 57.3 & 68.0 & 82.3 & 84.1 \\
\hline 1877 & 93.1 & 75.4 & 78.7 & 107.5 & 100.0 & 39.4 & 67.9 & 69.4 & 50.7 & 66.9 & 87.7 & 87.8 \\
\hline 1878 & 92.8 & 73.4 & 78.3 & 109.7 & 100.0 & 40.4 & 35.8 & 71.1 & 39.5 & 63.6 & 93.3 & 92.7 \\
\hline 1879 & 92.5 & 71.5 & 77.9 & 111.9 & 100.0 & 41.5 & 53.4 & 73.6 & 39.2 & 65.6 & 89.6 & 88.8 \\
\hline 1880 & 92.2 & 69.7 & 77.5 & 111.9 & 100.0 & 42.6 & 98.7 & 80.5 & 61.3 & 72.1 & 84.7 & 85.0 \\
\hline 1881 & 91.9 & 67.8 & 77.1 & 112.7 & 100.0 & 38.9 & 143.2 & 79.5 & 66.3 & 75.0 & 82.4 & 82.5 \\
\hline 1882 & 91.6 & 66.1 & 76.7 & 112.7 & 100.0 & 48.8 & 46.2 & 85.8 & 81.0 & 69.9 & 85.4 & 85.1 \\
\hline 1883 & 87.6 & 72.1 & 76.9 & 112.7 & 100.0 & 44.4 & 55.7 & 87.0 & 68.7 & 69.8 & 85.6 & 84.9 \\
\hline 1884 & 87.7 & 69.6 & 75.6 & 113.4 & 100.0 & 56.5 & 264.4 & 83.2 & 76.9 & 91.9 & 80.0 & 79.8 \\
\hline 1885 & 77.5 & 58.5 & 82.3 & 113.4 & 100.0 & 77.5 & 155.7 & 82.5 & 75.1 & 84.4 & 76.2 & 76.5 \\
\hline 1886 & 80.0 & 76.6 & 93.4 & 112.7 & 100.0 & 84.1 & 104.1 & 83.6 & 75.9 & 85.5 & 76.8 & 76.8 \\
\hline 1887 & 82.6 & 100.4 & 106.2 & 111.2 & 100.0 & 91.3 & 98.2 & 98.9 & 80.1 & 94.8 & 76.7 & 76.5 \\
\hline 1888 & 83.4 & 101.5 & 108.0 & 110.4 & 100.0 & 84.2 & 66.6 & 109.7 & 75.8 & 92.1 & 75.0 & 74.9 \\
\hline 1889 & 84.2 & 102.6 & 109.9 & 109.7 & 100.0 & 77.8 & 81.0 & 111.8 & 86.2 & 93.0 & 77.8 & 77.9 \\
\hline 1890 & 85.0 & 103.7 & 111.8 & 109.0 & 100.0 & 71.8 & 69.3 & 110.4 & 83.0 & 90.2 & 87.6 & 87.0 \\
\hline 1891 & 85.8 & 104.8 & 113.8 & 108.2 & 100.0 & 66.3 & 163.0 & 101.5 & 80.5 & 96.2 & 88.2 & 87.5 \\
\hline 1892 & 86.6 & 106.0 & 115.8 & 106.7 & 100.0 & 61.2 & 215.7 & 98.6 & 84.3 & 99.8 & 88.2 & 86.9 \\
\hline 1893 & 87.4 & 107.1 & 117.8 & 106.0 & 100.0 & 52.1 & 51.4 & 91.3 & 82.2 & 80.9 & 93.1 & 91.9 \\
\hline 1894 & 88.0 & 109.0 & 119.2 & 105.2 & 100.0 & 53.5 & 94.9 & 94.7 & 83.2 & 86.5 & 96.2 & 94.9 \\
\hline 1895 & 93.9 & 111.0 & 120.6 & 104.5 & 100.0 & 78.1 & 42.2 & 97.2 & 98.3 & 90.4 & 91.5 & 90.5 \\
\hline 1896 & 100.1 & 113.0 & 122.0 & 103.7 & 100.0 & 86.8 & 44.4 & 94.3 & 102.9 & 93.8 & 89.4 & 88.5 \\
\hline 1897 & 106.8 & 115.0 & 123.5 & 103.0 & 100.0 & 80.2 & 53.5 & 96.3 & 115.3 & 95.0 & 96.2 & 95.3 \\
\hline 1898 & 113.9 & 117.0 & 124.9 & 101.5 & 100.0 & 74.1 & 254.2 & 96.3 & 104.1 & 113.1 & 101.5 & 100.5 \\
\hline 1899 & 85.0 & 108.2 & 111.8 & 100.7 & 100.0 & 98.3 & 149.8 & 98.1 & 90.5 & 103.6 & 101.7 & 100.9 \\
\hline 1900 & 100.0 & 100.0 & 100.0 & 100.0 & 100.0 & 100.0 & 100.0 & 100.0 & 100.0 & 100.0 & 100.0 & 100.0 \\
\hline
\end{tabular}




\begin{tabular}{|c|c|c|c|c|c|c|c|c|c|c|c|c|}
\hline 1901 & 153.6 & 92.4 & 89.5 & 99.4 & 181.3 & 99.0 & 190.7 & 91.7 & 107.6 & 116.2 & 96.5 & 97.1 \\
\hline 1902 & 193.4 & 135.6 & 130.5 & 119.0 & 172.7 & 85.0 & 125.8 & 85.6 & 102.4 & 119.2 & 95.9 & 96.1 \\
\hline 1903 & 166.4 & 111.5 & 86.6 & 140.5 & 189.3 & 61.2 & 122.9 & 94.8 & 113.6 & 105.7 & 104.2 & 103.9 \\
\hline 1904 & 139.3 & 83.5 & 70.7 & 123.5 & 173.3 & 107.6 & 66.6 & 103.8 & 126.7 & 105.3 & 97.9 & 97.8 \\
\hline 1905 & 122.0 & 84.1 & 72.4 & 143.5 & 158.0 & 87.3 & 156.7 & 101.1 & 102.3 & 104.1 & 90.5 & 90.3 \\
\hline 1906 & 150.3 & 84.7 & 74.2 & 321.8 & 144.7 & 80.8 & 35.9 & 108.4 & 139.1 & 98.5 & 88.3 & 88.3 \\
\hline 1907 & 110.4 & 85.3 & 75.9 & 161.5 & 132.7 & 70.8 & 66.3 & 109.7 & 147.4 & 92.5 & 93.0 & 92.8 \\
\hline 1908 & 94.9 & 85.9 & 77.8 & 172.6 & 121.3 & 134.7 & 152.5 & 99.4 & 128.7 & 112.8 & 97.0 & 96.5 \\
\hline 1909 & 148.3 & 86.5 & 79.7 & 173.6 & 110.6 & 104.8 & 115.3 & 99.6 & 132.5 & 107.9 & 94.6 & 95.1 \\
\hline 1910 & 153.3 & 114.9 & 79.1 & 196.9 & 76.9 & 75.3 & 85.6 & 87.6 & 155.2 & 99.5 & 97.4 & 97.1 \\
\hline 1911 & 183.6 & 96.1 & 72.9 & 153.0 & 81.3 & 93.4 & 177.5 & 89.1 & 153.6 & 113.5 & 103.0 & 104.7 \\
\hline 1912 & 69.6 & 80.4 & 67.2 & 157.5 & 86.0 & 76.9 & 104.6 & 92.6 & 164.7 & 86.3 & 106.9 & 108.4 \\
\hline 1913 & 90.0 & 67.2 & 62.0 & 161.9 & 90.7 & 68.1 & 69.9 & 89.7 & 171.5 & 80.9 & [106.9] & [108.4] \\
\hline 1914 & 108.1 & 56.2 & 57.1 & 166.4 & 96.0 & 82.8 & 66.0 & 94.1 & 146.1 & 84.8 & [106.9] & [108.4] \\
\hline 1915 & 103.6 & 46.4 & 52.2 & 171.0 & 101.4 & 59.2 & 68.3 & 90.6 & 129.4 & 75.2 & 115.4 & 139.9 \\
\hline 1916 & 115.9 & 43.9 & 47.2 & 210.7 & 106.1 & 56.2 & 67.9 & 82.3 & 133.9 & 74.4 & 157.1 & 262.4 \\
\hline 1917 & 115.9 & 41.6 & 52.8 & 169.5 & 102.8 & 54.0 & 98.1 & 78.9 & 112.3 & 74.5 & 212.7 & 439.1 \\
\hline 1918 & 149.6 & 39.3 & 72.0 & 239.7 & 94.7 & 52.3 & 70.2 & 75.2 & 79.7 & 74.7 & 328.1 & 688.5 \\
\hline 1919 & 127.7 & 41.0 & 58.0 & 210.7 & 96.0 & 62.9 & 72.8 & 64.3 & 127.8 & 74.2 & 423.3 & 572.5 \\
\hline 1920 & 161,5 & 49,3 & 76,8 & 242,7 & 105,5 & 41,5 & 46,3 & 66,0 & 135,1 & 74,2 & 709.7 & 1,307 \\
\hline 1921 & 144.6 & 46.6 & 69.0 & 210.7 & 108.9 & 56.5 & 60.2 & 68.3 & 108.7 & 75.6 & 957.7 & 1,550 \\
\hline 1922 & 156.0 & 48.4 & 80.6 & 210.7 & 112.2 & 71.0 & 75.4 & 96.2 & 218.8 & 93.5 & 1,273 & 1,778 \\
\hline 1923 & 205.7 & 43.5 & 77.8 & 160.3 & 112.2 & 75.5 & 113.1 & 77.0 & 195.7 & 98.7 & 1,976 & 2,695 \\
\hline 1924 & 165.1 & 49.0 & 77.9 & 187.8 & 120.3 & 64.3 & 102.5 & 59.0 & 200.3 & 87.9 & 2,764 & 3,451 \\
\hline 1925 & 194.8 & 60.9 & 75.4 & 174.0 & 210.9 & 69.5 & 99.9 & 94.6 & 227.1 & 106.9 & 2,402 & 2,772 \\
\hline 1926 & 133.7 & 51.6 & 54.0 & 184.7 & 161.6 & 44.9 & 73.5 & 109.8 & 261.8 & 89.1 & 2,320 & 2,740 \\
\hline 1927 & 178.8 & 63.6 & 69.7 & 229.0 & 193.4 & 113.5 & 230.8 & 101.7 & 234.4 & 130.2 & 2,510 & 2,802 \\
\hline 1928 & 117.7 & 60.2 & 59.1 & 204.6 & 162.9 & 55.4 & 66.9 & 98.5 & 238.0 & 88.1 & 2,560 & 2,914 \\
\hline 1929 & 166.1 & 62.9 & 69.8 & 229.0 & 212.3 & 80.9 & 197.1 & 111.2 & 275.5 & 121.1 & 2,459 & 2,914 \\
\hline 1930 & 211.2 & 70.3 & 73.0 & 253.4 & 351.6 & 70.9 & 46.8 & 111.6 & 202.1 & 115.8 & 2,284 & 2,746 \\
\hline 1931 & 203.0 & 74.3 & 75.6 & 267.2 & 377.3 & 90.5 & 167.6 & 114.6 & 181.4 & 133.2 & 2,058 & 2,493 \\
\hline 1932 & 365.4 & 60.7 & 70.1 & 345.0 & 417.8 & 75.3 & 112.6 & 123.6 & 176.5 & 146.3 & 2,133 & 2,522 \\
\hline 1933 & 250.0 & 52.0 & 62.7 & 476.3 & 386.1 & 112.8 & 191.5 & 122.2 & 235.9 & 149.0 & 2,083 & 2,437 \\
\hline 1934 & 401.0 & 51.4 & 72.2 & 560.3 & 345.5 & 132.5 & 56.2 & 125.2 & 241.4 & 160.5 & 2,284 & 2,634 \\
\hline 1935 & 343.5 & 48.0 & 69.0 & 592.3 & 319.1 & 72.6 & 134.3 & 123.4 & 264.2 & 143.3 & 1,983 & 2,409 \\
\hline 1936 & 132.8 & 50.7 & 52.3 & 627.4 & 321.1 & 45.5 & 70.9 & 128.7 & 297.4 & 105.5 & 2,108 & 2,522 \\
\hline 1937 & 225.4 & 58.3 & 59.3 & 870.2 & 370.5 & 98.7 & 253.0 & 127.1 & 321.4 & 155.5 & 2,334 & 2,970 \\
\hline 1938 & 242.7 & 53.2 & 59.5 & 700.7 & 370.5 & 134.2 & 86.8 & 141.6 & 225.8 & 148.1 & 2,234 & 2,886 \\
\hline 1939 & 297.0 & 65.1 & 60.4 & 734.3 & 377.3 & 94.6 & 197.1 & 158.4 & 287.3 & 163.1 & 2,183 & 2,886 \\
\hline 1940 & 151.5 & 65.2 & 44.1 & 845.7 & 383.3 & 63.5 & 89.6 & 158.4 & 277.3 & 125.9 & 2,459 & 3,670 \\
\hline 1941 & 253.2 & 69.1 & 53.2 & 909.9 & 388.8 & 90.4 & 234.8 & 149.9 & 347.3 & 163.1 & 2,886 & 4,287 \\
\hline 1942 & 295.6 & 64.8 & 72.5 & 804.5 & 519.2 & 101.2 & 97.8 & 106.1 & 242.3 & 152.3 & 3,237 & 4,959 \\
\hline 1943 & 166.5 & 60.2 & 58.1 & 758.7 & 554.4 & 170.9 & 224.7 & 121.5 & 139.4 & 164.8 & 3,664 & 6,192 \\
\hline 1944 & 207.6 & 69.7 & 76.2 & 651.9 & 557.1 & 177.8 & 92.9 & 156.4 & 215.2 & 171.2 & 4,542 & 6,948 \\
\hline 1945 & 177.5 & 45.3 & 71.7 & 458.0 & 461.8 & 124.6 & 103.5 & 153.8 & 284.3 & 145.9 & 4,743 & 6,752 \\
\hline 1946 & 286.5 & 69.3 & 86.4 & 641.2 & 584.8 & 82.0 & 114.0 & 121.5 & 375.6 & 159.8 & 5,195 & 6,612 \\
\hline 1947 & 196.2 & 59.2 & 88.8 & 882.4 & 636.9 & 123.9 & 238.3 & 124.5 & 339.4 & 173.5 & 5,094 & 6,948 \\
\hline 1948 & 200.7 & 63.9 & 72.5 & 938.9 & 633.5 & 100.2 & 74.0 & 178.3 & 321.1 & 161.4 & 5,318 & 6,864 \\
\hline 1949 & 228.6 & 42.8 & 87.4 & 795.4 & 491.5 & 97.1 & 251.4 & 199.0 & 311.4 & 173.3 & 5,623 & 7,196 \\
\hline 1950 & 324.4 & 86.1 & 99.7 & 1241.1 & 703.8 & 106.9 & 102.3 & 185.2 & 431.6 & 199.0 & 5,135 & 7,028 \\
\hline 1951 & 327.1 & 76.9 & 113.6 & 1448.7 & 864.7 & 116.3 & 271.0 & 180.6 & 472.4 & 228.0 & 5,364 & 7,360 \\
\hline 1952 & 326.6 & 81.3 & 102.9 & 1442.6 & 653.8 & 71.1 & 133.6 & 194.0 & 300.1 & 187.0 & 5,592 & 7,525 \\
\hline 1953 & 389.1 & 62.4 & 107.1 & 1441.1 & 697.1 & 143.8 & 311.3 & 205.7 & 340.0 & 234.6 & 5,240 & 7,360 \\
\hline 1954 & 440.7 & 73.4 & 114.4 & 1573.9 & 667.3 & 149.3 & 123.8 & 214.5 & 323.9 & 227.6 & 5,263 & 7,196 \\
\hline 1955 & 286.5 & 72.8 & 90.9 & 1877.7 & 687.6 & 138.9 & 175.5 & 210.3 & 329.9 & 211.5 & 5,219 & 7,360 \\
\hline 1956 & 314.8 & 80.4 & 100.4 & 1644.1 & 685.6 & 134.4 & 238.0 & 194.7 & 301.9 & 215.5 & 5,764 & 7,608 \\
\hline 1957 & 449.4 & 71.2 & 118.7 & 1659.4 & 744.4 & 117.3 & 257.9 & 208.0 & 287.6 & 234.6 & 5,695 & 7,608 \\
\hline
\end{tabular}

Appendix table sources: see text 
Price indices for foodstuffs and total are based on linked index taking foodstuffs and general price indices from Justino (1991, p. 24) for 1865-1912, Valério (1984, p. 103) for 1914-30 and 1927-47, and Neves (1994, pp. 198-200) for 1947-57 (the base years are, respectively, 1863-86, 1914, 1927 and 1977). Due to lack of data, it was assumed that R remained constant between 1912 and 1914.

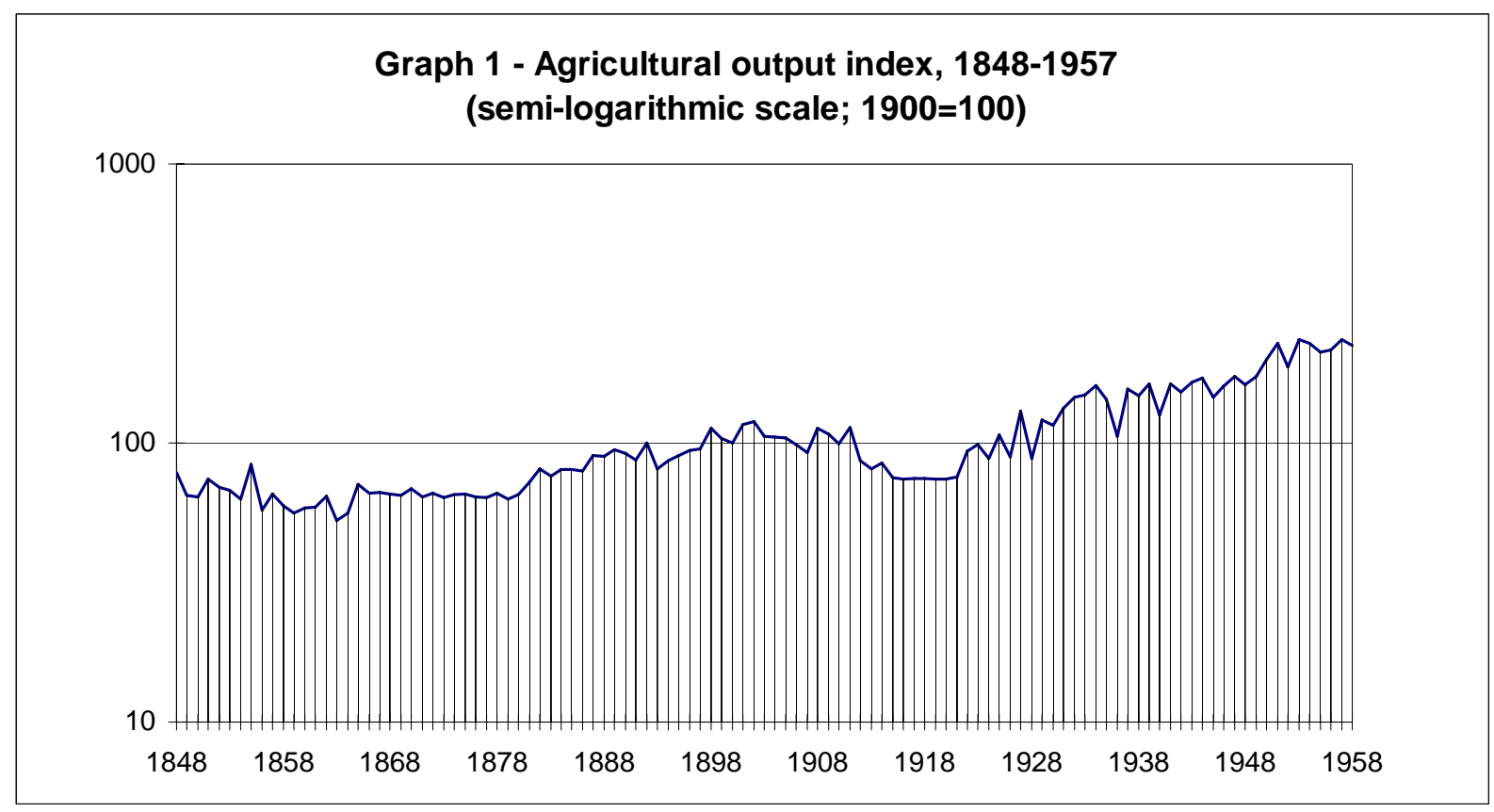

Source: Appendix table.

\footnotetext{
${ }^{*}$ Previous versions of this paper were presented at seminars at the New York University and the European University Institute (Florence). I would like to thank participants for their comments as well as two anonymous referees. The usual caveat applies. Forthcoming, European Review of Economic History, 7, 2003.

${ }^{1}$ See Soares (1873), Pery (1875), Pereira (1915), Gomes (1920), Basto (1936) and Gomes et
} 
al. (1944).

${ }^{2}$ See Lains and Sousa (1998, tab. 3) and Batista et al. (1997, p. 13).

${ }^{3}$ For more details see Lains (1995, app. A) and Lains and Sousa (1998). The original 12 sectors index for 1910-58 has the same peak years our 9 sectors index and similar peak-topeak rates of growth, except for a slightly lower increase for 1927-51 (2.0\% vs. 2.4\%).

${ }^{4}$ This is shown in Lains (1995, app. A) regarding an earlier version of the agricultural output index. The underestimation of output is common to most countries' estimates (van Zanden 1991, p. 217).

${ }^{5}$ The 1882 peak will subsequently be excluded from the analysis in this paper because we lack data for that year for agricultural inputs.

${ }^{6}$ Federico's (2000) estimates for Portugal are based on the same index as this paper. On the comparative performance of European agriculture in the same period see also Eddie (1968)

${ }^{7}$ The sharp fall in the unused but fit area during the latter part of the nineteenth century is compatible with the growth of agricultural output and land productivity (Lains 1995, appendix A). Overall, the evolution of the use of land in Portugal is quite well documented, albeit not in a yearly basis. See Pery (1875), Pereira (1915), Basto (1936), and Gomes et al. (1944). The official publication Estatística Agrícola (1957, p. 1) provides a summary of the evolution of the use of land, based on those works and on official Census data. See also Lains and Sousa (1998), Lains (1998) and, for the southern cereal production region of Alentejo, Fonseca (1996, pp. 155-9). In this respect, the range of experiences within Europe is large. Whereas in Belgium, for example, the pattern of extensive growth came to a halt in the 1860s (Gadisseur 1973), in Poland the area under crop still increased during the second half of the nineteenth century (Kostrowicka 1984).

${ }^{8}$ The growth of meat output is a good proxy for the growth of animal output, as can be ascertained by comparing the two indices available for 1910-58 in Batista et al. (1997, p. 21). 
${ }^{9}$ Census data for female labour force, show a sharp decline from 1900 to 1930 and an increase from 1930 to 1950 . Thus, total male and female labour force in the agricultural sector declined by $-0.6 \%$ per year, during $1900-30$ (instead of $-0.14 \%$ for $1902-27$, as in table 4 ), and increased by $1.0 \%$ during $1930-50$ (instead of $0.9 \%$ for $1927-51$, in the same table). This implies that labour productivity growth in table 4 is underestimated by the use of male labour force only, for 1902-27, and slightly overestimated, for 1927-51. For Census data, see Nunes (1991).

${ }^{10}$ See Silva (1970, pp. 115 and 170-1). Lains (1990, p. 45) provides an alternative estimate based on the assumption that the proportion of active population employed in agriculture was that of the European norm. According to that estimate, agricultural labour force increased by 0.6\% per year during 1865/70-1900. Castro (1945, p, 28) provides another estimate for agricultural population in 1864, which implies a growth rate of $0.56 \%$ per year for 1864 1900. Labour participation rates are as follows: 1890: 66.2\%; 1900: 66.6\%; 1911; 65.3\%; 1930: 59.0\%; 1940: 61.2\%; 1950: 60.9\% (Silva 1970, pp. 141, 170-1). We only include male population in the 20-59 bracket in order to make our index more homogeneous. Pereira e Estácio (1968, pp. 14-15) estimate that the units of man-work in the 15-19 bracket as $70 \%$ of the 20-59 bracket.

${ }^{11}$ For a comparative perspective on Portuguese agriculture in the 1945-90 period, see Lains (1994).

${ }^{12}$ If we consider the growth of the area under crop, which does not include the area left fallow and pasture, the picture emerges slightly different. In fact, from 1927 to 1951, the area under crop increased at $0.8 \%$ per year, which implies that land productivity increased at a slower rate, namely, $1.5 \%$ per year.

13 The sectorial productivity gap is defined as follows: (100-AGY) / (100-AGLAB) $\mathrm{x}$ AGLAB / AGY, where AGLAB and AGY are, respectively, labour and output shares. The 
values for Portugal are: c. $1870=2.71 ; 1890=2.28 ; 1910=2.4 ; 1930=2.37 ; 1950=2.05$. See Crafts (1984).

${ }^{14}$ For the period before 1910, these shares are only indicative, as they were estimated by extrapolating backwards output data for 1910 and the growth of the services sector was taken as the growth of active population in the sector. See Lains (1998).

${ }^{15}$ See Chenery and Syrquin (1975, tab. 3). See also Crafts (1984, tabs. 2, 4 and 7). For the size of the agricultural sector, see Lains (1998), Molinas and Prados (1989, tab. 2) and Zamagni (1993, tab. 0.7). For relative income levels, see also Lains (2002).

${ }^{16}$ For factor shares, see also Crafts (1985, pp. 78-84) and Lains (1990).

${ }^{17}$ Gomes et al. (1944, p. 114) estimates that half of the liquid fuel consumption in agriculture was employed by threshing machines (there was a substantial use of fuels for irrigation, as well). We assume that the growth of other machinery parallels that of threshers. The use of tractors remained rather limited, as in 1955 there were only 4,495 tractors in the whole country (Caldas 1957, p. 4).

${ }^{18}$ See also, among others, Pereira e Estácio (1968) and O’Brien and Keyder (1978).

${ }^{19}$ Van Zanden (1991, pp. 219-20) finds a similar positive correlation between levels of output per hectare and output per head for his sample of 15 European countries, in 1870.

${ }^{20}$ Such positive correlation is also true for Portuguese regional data, in 1960. See Pereira and Estácio (1968, pp. 33-4). See also Dovring (1956, pp. 103 ff.)

${ }^{21}$ According to Andermann et al. (1998), the increase in land productivity was also the major force driving up labour productivity in France and Germany, during 1880-1940.

${ }^{22}$ For lack of data, we cannot carry this analysis for the years before 1918. See though Lains (1990), where it is shown that yields of the main crops also did not change significantly before 1914 . 
${ }^{23}$ Portugal was thus in the 1950s at the level of Germany, Belgium and the Netherlands in 1910 (van Zanden 1991, pp. 231-2). According to Sanz (1994, p. 250), Spain’s agriculture used 18 kg/ha of fertilizers, in 1930-1935 (see also Gallego 1986). Gomes (1920, pp. 55-6) puts the average use of chemical fertilizers in $1903-14$ at $100,000 \mathrm{t}$ or $20 \mathrm{~kg} / \mathrm{ha}$. The sharp decline thereafter was due to effects of World War I, as fertilizers were imported and domestic production started in 1917. There was an important change in the type of fertilizers used in Portuguese agriculture, though, as before World War I they were mainly phosphates, overwhelmingly used in the wheat growing Alentejo district, whereas in the 1950s, half of the fertilizers were nitrogen and potassium. See also Pintado (1964, p. 76), Baptista (1993, p. 408) and Reis (1993, p. 76).

${ }^{24}$ Yields for most crops, with the exception of rice, remained relatively stagnant in the following period from 1950-74. Contrarily, animal output productivity increased slightly. See Girão (1980, pp. 29-69).

${ }^{25}$ Changes in product mix towards more labour intensive sectors would lead to an increase in female agricultural labour force, and that is what the Census data show. In fact, female labour force expanded at $1.9 \%$ per year (although from a low point in 1930). Yet, the fact that we use male labour only, does not affect the results, however, because the share of female labour force registered in the Census in 1930 was extremely low (13\% of total labour force) and thus the growth rate of male labour force is only slightly inferior to the growth rate of total labour force, according to the Census (namely, 0.9\% per year versus 1.0\%). See Nunes (1991).

${ }^{26}$ See also van Zanden (1991, pp. 221-3).

${ }^{27}$ Van Zanden (1991, p. 223) concludes that productivity differences among his sample of 15 countries, in 1870, did not depend of differences of the product mix, but he only considers differences in the proportion of vegetable/animal output. Hunt and Pam (2001) argue that the shift from vegetable to animal output is not necessarily the most important source of total 
productivity growth through shifts in the product mix.

${ }^{28}$ Data from Estatística Agrícola (1957, pp. $135-7$ and 139). There is no correspondent data for consumption of fruits and vegetables. 